\title{
PROBLEM-BASED LEARNING: UPAYA MENINGKATKAN MOTIVASI BELAJAR SISWA PADA MATA PELAJARAN PAI DI SMK NEGERI 3 TEBO
}

\author{
ZIPLIN \\ SMK Negeri 3 Tebo, Jambi \\ e-mail :ziplinstikom@gmail.com
}

\begin{abstract}
ABSTRAK
Penelitian ini bertujuan untuk meningkatkan motivasi belajar mata pelajaran Pendidikan Agama Islam yang mengacu pada penerapan model pembelajaran Problem-Based Learning. Penelitian ini menggunakan metode penelitian tindakan kelas yang terdiri dari dua siklus, meliputi kegiatan perencanaan, pelaksanaan, observasi, dan refleksi. Subjek penelitian adalah siswa kelas XI IPS-1 SMK Negeri 3 Tebo Tahun Pelajaran 2019/2020. Data pelaksanaan proses pembelajaran oleh guru dilaksanakan melalui lembar observasi proses pembelajaran, data respon siswa terhadap proses pembelajaran dilaksanakan melalui lembar angket respon siswa, data motivasi belajar siswa dilaksanakan melalui lembar observasi motivasi belajar siswa, sedangkan data perubahan perilaku motivasi belajar siswa dilaksanakan melalui lembar angket perubahan perilaku motivasi belajar. Hasil penelitian menunjukkan pada siklus I, pelaksanaan proses pembelajaran, respon siswa terhadap proses pembelajaran, motivasi belajar siswa, danpPerubahan motivasi belajar siswa berada pada kategori belum berhasil. Sedangkan pada siklus II, kegiatan tersebut berada pada kategori berhasil.
\end{abstract}

Kata Kunci: Motivasi Belajar, Problem-Based Learning

\section{PENDAHULUAN}

Pada abad ini tuntutan persaingan di segala bidang membutuhkan keterampilan (skill) tingkat tinggi atau Higher Order Thinking Skill (HOTS), begitu juga untuk mata pelajaran Pendidikan Agama Islam (PAI). Peserta didik harus memiliki sikap, pengetahuan, dan keterampilan yang mampu menunjukkan kemampuan bersaing yang kreatif, inovatif dan produktif. Kompetensi kemampuan berpikir tingkat tinggi (HOTS) tidak bisa dicapai dengan motivasi belajar yang rendah. Peserta didik harus mempunyai semangat belajar tinggi, rasa ingin tahu yang besar, semangat pantang menyerah dalam menyelesaikan tugas belajar, serta kritis dalam menghadapi masalah yang berkembang di masyarakat. Kondisi pembelajaran PAI pada siswa kelas XI IPS-1 SMK Negeri 3 Tebo Tahun Pelajaran 2019/2020 saat ini masih jauh dari tujuan yang diharapkan. Pembelajaran yang diharapkan akan melibatkan keaktifan siswa dalam bertanya jawab juga mengkritisi materi pembelajaran untuk menjawab permasalahan kehidupan, belum terwujud. Namun, sebagian besar siswa tidak aktif dalam belajar saat melaksanakan proses pembelajaran. Siswa cenderung diam dan pasif dalam mengikuti pembelajaran.

Indikasi rendahnya motivasi belajar siswa kelas XI IPS-1 SMK Negeri 3 Tebo Tahun Pelajaran 2019/2020 tampak pada kurang semangatnya siswa mengikuti pembelajaran, kurangnya rasa ingin tahu terhadap materi pelajaran, rendahnya aktifitas bertanya dan menyampaikan pendapat, dan rendahnya semangat membaca sumber informasi tentang materi pelajaran. Motivasi belajar seharusnya lebih banyak muncul dari semangat dalam diri berupa semangat untuk berprestasi, semangat untuk memiliki ketrampilan, dan semangat ke depan meraih cita-cita. Tetapi yang sering terjadi siswa mau membaca materi pelajaran hanya saat mau evaluasi. Belajar belum sebagai kebutuhan, tetapi karena keterpaksaan.

Berdasarkan kenyataan tersebut sudah seharusnya guru sebagai fasilitator dan motivator untuk mengupayakan perubahan perencanaan dan pelaksanaan pembelajaran agar mendapatkan solusi dari pemasalahan yang ada. Penelitian ini diharapkan dapat memberikan solusi atas permasalahan rendahnya motivasi belajar peserta didik pada mata pelajaran PAI dengan menerapkan model pembelajaran Problem-Based Learning. Model Problem-Based Learning merupakan salah satu cara belajar yang menuntut siswa aktif melakukan penyelidikan dalam 
menyelesaikan permasalahan. Pembelajaran akan dapat membentuk kemampuan berpikir tingkat tinggi dan meningkatkan kemampuan siswa untuk berpikir kritis. Siswa akan dipaksa oleh proses pembelajaran yang mengharuskan dia untuk berkolaborasi, berpikir kritis, mencari tahu, bertanya, menjawab, menyampaikan kembali hasil belajarnya. Secara khusus, tujuan dari penelitian adalah: (1) untuk meningkatkan motivasi belajar pada mata pelajaran Pendidikan Agama Islam melalui model pembelajaran Problem-Based Learning bagi siswa kelas XI IPS1 SMK Negeri 3 Tebo Tahun Pelajaran 2019/2020, dan (2) untuk mengetahui bagaimana langkah- langkah penerapan model pembelajaran Problem-Based Learning untuk meningkatkan motivasi belajar pada mata pelajaran Pendidikan Agama Islam bagi siswa kelas XI IPS-1 SMK Negeri 3 Tebo Tahun Pelajaran 2019/2020.

Pemberian motivasi belajar PAI merupakan upaya sadar dan terencana dalam menyiapkan siswa untuk mengenal, memahami, menghayati hingga mengimani, bertakwa, dan berakhlak mulia dalam mengamalkan ajaran agama Islam dari sumber utamanya yaitu kitab suci Al-Quran dan Hadits, melalui kegiatan bimbingan, pengajaran, latihan, serta penggunaan pengalaman. Disertai tuntunan untuk menghormati penganut agama lain dalam hubungannya dengan kerukunan antar umat beragama dalam masyarakat hingga terwujud kesatuan dan persatuan bangsa (Depdiknas, 2003: 7). Pendidikan agama berbeda dengan pengajaran agama. Pendidikan agama berarti usaha-usaha secara sistematis dan pragmatis dalam membantu anak didik agar supaya mereka hidup sesuai dengan ajaran agama, sedangkan pengajaran agama berarti pemberian pengetahuan agama kepada anak, agar supaya mempunyai ilmu pengetahuan agama (Zuhairini, 1983: 27). PAI adalah suatu usaha bimbingan dan asuhan terhadap anak didik agar nantinya setelah selesai dari pendidikan dapat memahami apa yang terkandung dalam Islam secara keseluruhan, menghayati makna dan maksud, serta tujuannya, dan pada akhirnya dapat mengamalkan serta menjadikan ajaran-ajaran agama Islam yang telah dianutnya sebagai pandangan hidup (way of life), sehingga dapat mendatangkan keselamatan dunia dan akhirat (Achmadi, 1992: 20). Pembelajaran PAI merupakan usaha sadar yang diberikan kepada siswa untuk menyiapkan siswa agar memahami, menghayati, dan mengamalkan ajaran-ajaran agama Islam serta menjadikannya sebagai pedoman hidup untuk mampu menyelamatkan dari permasalahan-permasalahan kehidupan sehingga tercapai keselamatan dunia dan akhirat.

Proses pembelajaran merupakan kegiatan interaksi antara guru dengan siswa, siswa dengan siswa, siswa dengan lingkungan yang bertujuan mencapai kompetensi pembelajaran. Dalam proses pembelajaran diperlukan seting pembelajaran yang tepat sesuai dengan spesifikasi materi dan tujuan yang akan dicapai dalam materi pelajaran dimaksud. Model dan proses pembelajaran akan menjelaskan makna kegiatan- kegiatan yang dilakukan oleh guru selama pembelajaran berlangsung. Apabila guru tidak mengetahui apa yang sebenarnya terjadi dalam pikiran siswanya untuk engetahui sesuatu, maka diapun tidak akan dapat memberi dorongan yang tepat kepada mereka yang sedang belajar. Para siswa akan mudah melupakan pelajaran yang diterimanya, jika guru tidak memberikan penjelasan yang benar dan menyenangkan (Syaiful Sagala, 2010: 173). Model pembelajaran adalah kerangka konseptual yang digunakan sebagai pedoman dan acuan dalam melakukan sebuah kegiatan. Pengembangan sistem intruksional dalam proses menciptakan situasi dan kondisi tertentu memungkinkan siswa berinteraksi sehingga terjadi perubahan tingkah laku (Hamdani, 2011: 147).

Dalam lampiran Permendikbud Nomor 103 Tahun 2014 tentang Pembelajaran pada Pendidikan Dasar dan Menengah menyatakan bahwa, model pembelajaran merupakan suatu bentuk pembelajaran yang memiliki nama, ciri, sintak, pengaturan, dan budaya misalnya discovery learning, project-based learning, problem-based learning, inquiry learning. Model pembelajaran yang dikembangkan harus dapat mengembangkan kompetensi sikap, kompetensi pengetahuan, dan kompetensi ketrampilan. Model pembelajaran adalah bentuk pembelajaran yang tergambar dari awal sampai akhir yang disajikan secara khas oleh guru. Problem-Based Learning (PBL) atau disebut juga dengan Strategi Pembelajaran Berbasis Masalah (SPBM) ialah sebuah strategi pembelajaran yang berpusat pada peserta didik dengan cara menghadapkan para peserta didik tersebut dengan berbagai masalah yang dihadapi dalam 
kehidupannya untuk dianalisis dan disintesis dalam usaha mencari pemecahan atau jawabannya (Abuddin Natta, 2009: 243). Problem-Based Learning juga dikenal dengan istilah pembelajaran proyek (project teaching), pendidikan berdasar pengalaman (experience-based education), pembelajaran autentik (authentic learnin), dan pembelajaran berakar pada kehidupan (anchored instruction). Pembelajaran ini semua sama-sama berakar dengan adanya masalah dalam kehidupan sehari-hari (Trianto Ibnu Badar Al-Tabany, 2014: 63). Problem-Based Learning merupakan pembelajaran yang penyampaiannya dilakukan dengan cara menyajikan suatu permasalahan, mengajukan pertanyaan-pertanyaan, memfasilitasi penyelidikan, dan membuka dialog. Permasalahan yang dikaji hendaknya merupakan permasalahan kontekstual yang ditemukan oleh peserta didik dalam kehidupan sehari-hari (Ridwan Abdullah Sani, 2018: 127). Problem-Based Learning merupakan model pembelajaran yang dimulai dari masalah yang terjadi dalam kehidupan nyata, kemudian dianalisa, dicari solusi masalah melalui pengetahuan. Dengan demikian mengantarkan siswa memiliki pengalaman konkret, membangun kemampuan berpikir tingkat tinggi dengan mencari pengetahuan sendiri untuk memecahkan masalah.

\section{METODE PENELITIAN}

Penelitian ini menggunakan penelitian tindakan kelas (PTK), merupakan rangkaian penelitian yang dilakukan secara siklus untuk memecahkan masalah. PTK bertujuan untuk memperbaiki kinerja, sifatnya kontekstual dan hasilnya tidak untuk digeneralisasi. Penelitian tindakan kelas dilaksanakan dalam proses penyajian berdaur (cyclical) yang terdiri dari 4 tahap, yaitu: merencanakan, melakukan tindakan, mengamati, dan merefleksi.

Penelitian ini dilaksanakan di kelas XI IPS-1 SMK Negeri 3 Tebo Tahun Pelajaran 2019/2020. SMK Negeri 3 Tebo terletak di wilayah ibukota Kabupaten Tebo Provinsi Jambi. Prosedur penelitian dilaksanakan dalam 2 siklus dan pada setiap siklus terdiri dari tiga (3) pertemuan. Setiap siklus terdiri dari satu rangkaian kegiatan yang meliputi 4 (empat) tahapan, yaitu: (1) perencanaan, (2) pelaksanaan tindakan, (3) pengamatan, dan (4) refleksi.

\section{HASIL DAN PEMBAHASAN}

Hasil observasi peningkatan motivasi belajar pada mata pelajaran Pendidikan Agama Islam melalui penerapan model pembelajaran Problem-Based Learning bagi siswa kelas XI IPS-1 SMK Negeri 3 Tebo Tahun Pelajaran 2019/2020 pada siklus 1 dan siklus II adalah sebagai berikut:

Tabel 1. Hasi Observasi Siklus I dan Siklus II

\begin{tabular}{llll}
\hline \multirow{2}{*}{ No } & \multirow{2}{*}{ Komponen Observasi } & \multicolumn{2}{c}{ Prosentase Hasil } \\
\cline { 3 - 4 } & & Siklus I & Siklus II \\
\hline 1 & Penerapan Model Pembelajaran PBL & $86.96 \%$ & $100 \%$ \\
\hline 2 & Respon Siswa Terhadap Model Pembelajaran PBL & $78.13 \%$ & $90 \%$ \\
\hline 3 & Motivasi Belajar Siswa & $75.01 \%$ & $94.53 \%$ \\
\hline 4 & Perubahan Perilaku Motivasi Belajar Siswa & $6.71 \%$ & $89.06 \%$ \\
\hline
\end{tabular}

Hasil observasi sebagaimana pada tabel 1 di atas diketahui adanya peningkatan hasil dari siklus I dan siklus II. Hasil tersebut menunjukkan bahwa dengan penerapan model pembelajaran Problem-Based Learning mempengaruhi siswa menjadi aktif dan responsif dalam mengikuti proses pembelajaran. Perilaku- perilaku motivasi belajar muncul sebagai dampak positif adanya semangat dari dalam diri dan pengaruh dari luar berupa situasi dan kondisi pembelajaran yang menyenangkan, yang mengantarkan pada kenyamanan siswa aktif untuk belajar.

Motivasi belajar adalah kecenderungan siswa dalam melakukan kegiatan belajar yang didorong oleh hasrat untuk mencapai prestasi atau hasil belajar sebaik mungkin (Nashar, 2004: 42). Secara umum dorongan belajar bisa muncul karena adanya semangat dari dalam diri, maupun pengaruh dari luar. Semangat dari dalam diri berupa keingin yang mengantar meraih 
cita-cita masa depan, sedangkan dorongan dari luar berupa suasana belajar, lingkungan yang kondusif dan menjanjikan. Motivasi belajar adalah dorongan internal dan eksternal pada siswasiswa yang sedang belajar untuk mengadakan perubahan tingkah laku, pada umumnya dengan beberapa indikator atau unsur yang mendukung (Hamzah B. Uno, 2017: 23). Hal itu mempunyai peranan besar dalam keberhasilan seseorang dalam belajar. Indikator motivasi belajar dapat diklasifikasikan sebagai berikut: (1) adanya hasrat dan keinginan berhasil; (2) adanya dorongan dan kebutuhan dalam belajar; (3) adanya harapan dan cita-cita masa depan; (4) adanya penghargaan dalam belajar; (5) adanya kegiatan yang menarik dalam belajar; (6) adanya lingkungan belajar yang kondusif, sehingga memungkinkan seseorang siswa dapat belajar dengan baik. Belajar sangat diperlukan adanya motivasi. Motivation is an essential conditional of learning. Hasil belajar akan menjadi optimal jika ada motivasi. Makin tepat motivasi yang diberikan, akan makin berhasil pula pelajaran tersebut. (Sardiman, 1986: 84). Motivasi belajar merupakan dorongan dari dalam diri sendiri (intrinsik) dan juga faktor lain (ekstrinsik) untuk belajar dalam rangka mencapai tujuan. Motivasi belajar ditunjukkan dengan indikator-indikator yang mengarah pada keingin tahuan, kebutuhan memahami materi secara luas, dan harapan masa depan dalam belajar. Motif dapat dikatakan sebagai daya penggerak dari dalam dan di dalam subyek untuk melakukan aktifitas-aktifitas tertentu demi mencapai suatu tujuan (Sardiman, 1986: 73). Motivasi dapat diartikan sebagai daya penggerak yang telah menjadi aktif. Motif menjadi aktif pada saat-saat tertentu, terutama bila kebutuhan untuk mencapai tujuan sangat dirasakan/mendesak. Beberapa psikolog menyebut motivasi sebagai konstruk hipotesis yang digunakan untuk menjelaskan keinginan, arah, intensitas, dan keajegan perilaku yang diarahkan oleh tujuan (Hamzah, 2017: 3). Dalam motivasi tercakup konsepkonsep, seperti kebutuhan untuk berprestasi, kebutuhan berafiliasi, kebiasaan, dan keingintahuan seseorang terhadap sesuatu. Hal ini menujukkan bahwa motivasi merupakan energi yang muncul dari dalam diri seseorang yang tampak pada kegiatan fisik manusia sebagai respon dari suatu tujuan/menyangkut soal kebutuhan, sehingga motivasi menjelaskan sikap kebutuhan seseorang untuk berprestasi, berafiliasi, berkebiasaan, dan keingintahuan seseorang terhadap sesuatu.

\section{KESIMPULAN}

Penerapan model pembelajaran Problem-Based Learning untuk meningkatkan motivasi belajar pada mata pelajaran Pendidikan Agama Islam bagi siswa kelas X1 IPS-1 pada SMK Negeri 3 Tebo Tahun Pelajaran 2019/2020 dilakukan dengan langkah-langkah pembelajaran yang runtut dan jelas meliputi kegiatan awal yang intinya menyiapkan psikis dan fisik siswa untuk belajar, penjelasan materi pelajaran lengkap dengan kompetensi dan penilaian yang dilakukan, dilanjutkan kegiatan inti meliputi sintak pembelajaran Problem-Based Learning; 1) orientasi siswa pada masalah, 2) mengorganisasi siswa untuk belajar, 3) membimbing penyelidikan individu dan investigasi kelompok, 4) mengembangkan dan menyajikan hasil karya, 5) menganalisis dan mengevaluasi proses pemecahan masalah, dan ditutup dengan kegiatan akhir/penutup yang intinya melakukan refleksi terhadap proses pembelajaran yang dilakukan dan menyampaikan informasi rencana pembelajaran berikutnya. Penerapan model pembelajaran Problem-Based Learning dapat meningkatkan motivasi belajar pada mata pelajaran Pendidikan Agama Islam bagi siswa kelas X1 IPS-1 pada SMK Negeri 3 Tebo Tahun Pelajaran 2019/2020. Hal tersebut ditunjukkan oleh peningkatan motivasi belajar siswa yang signifikan yaitu mencapai $94.53 \%$, dan perubahan perilaku motvasi belajar siswa mencapai $89.06 \%$.

\section{DAFTAR PUSTAKA}

A.M., S. 2016. Interaksi \& Motivasi Belajar Mengajar. Jakarta: Rajawali Pers.

Achmadi. 1992. Islam sebagai Paradigma Ilmu Pendidikan. Yogyakarta: Aditya Media.

Al-Tabany, T. I. 2014. Mendesain Model Pembelajaran Inovatif, Progresif, dan Kontekstual. Jakarta: Prenada Media Group. 
Arikunto, S. 2008. Penelitian Tindakan Kelas. Bandung: Bumi Aksara.

Hamzah, B. Uno. 2019. Teori Motivasi \& Pengukurannya-Analisis di bidang Pendidikan. Jakarta: Bumi Aksara.

Habibah Sukmini Arief, Maulana, Ali Sudin. 2016. "Meningkatkan Motivasi Belajar melalui Pendekatan Problem-Based Learning." Pena Ilmiah, Vol. 1 No.1

Hamdani. 2010. Strategi Belajar Mengajar. Bandung: Pustaka Setia.

Nasher. 2004. Peranan Motivasi dan Kemampuan Awal dalam Kegiatan Pembelajaran. Jakarta: Delia Press.

Nasional, D. P. 2003. Standar Kompetensi Mata Pelajaran Pendidikan Agama Islam. Jakarta.

Nata, A. 2009. Perspektif Islam tentang Strategi Pembelajaran. Jakarta: Kencana. Sagala, S. 2010. Konsep dan Makna Pembelajaran. Bandung: Alfabeta.

Sani, R. A. 2018. Pembelajaran Saintifik untuk Implementasi Kurikulum 2013. Jakarta: Bumi Aksara.

Sugiyono. 2011. Metode Penelitian Pendidikan, Pendekatan Kualitatif, Kuantitatif R\& D. Bandung: Alfabeta.

Syaifulloh, A. "Pengaruh Strategi Problem-Based Learning (PBL) terhadap Motivasi dan Hasil Belajar Ppeserta Didik pada Mata Pelajaran Fiqh di MA. Khozinatul 'Ulum Blora Jawa Tengah.” Wahana Akademika, Volume 3 Nomor 2, Oktober 2016

Syamsudin, A. 1996. Psikologi Kependidikan. Bandung: PT. Remaja Rosda Karya.

Zuhairini, D. 1983. Metodik Khusus Pendidikan Agama. Surabaya: Usaha Nasional. 